Dr DUNJA DOBAJA, asistent sa doktoratom

Institut za noviju istoriju

Ljubljana, Republika Slovenija

dunja.dobaja@inz.si

originalan naučni rad

UDK: 614.2(497.4)(091)

primljeno: 25. septembar 2017.

prihvaćeno: 28. mart 2018.

https://doi.org/10.29362/ist20veka.2018.2.dob.55-68

\title{
BOLNICE U KRALJEVINI JUGOSLAVIJI - „USKRAĆENE“ USTANOVE KURATIVNE STRUKE. PRIMER OPŠTE BOLNICE U LJUBLJANI
}

APSTRAKT: Prostorni, finansijski i personalni problemi konstanta su bolnica u različitim periodima. U tom pogledu ni Dravska banovina, odnosno Kraljevina Jugoslavija, nije bila izuzetak. Predmet članka jeste nedostatak prostora Opšte državne bolnice u Ljubljani, kao centralne bolnice u upravnom središtu Dravske banovine. Ova problematika je prikazana u kontekstu jugoslovenskih odnosa u vezi sa problemom bolnica i zalaganjem za njegovo rešavanje.

KLJUČNE REČI: bolnice, Kraljevina Jugoslavija, Dravska banovina, Opšta državna bolnica u Ljubljani, kurativna medicina

\section{Uvod}

Opšta državna bolnica u Ljubljani suočavala se sa dva osnovna problema: prenatrpanost i nedovoljna finansijska sredstva određena budžetom. Sa tim problemima bolnice se suočavaju i danas, s tom razlikom što je tokom razmatranog razdoblja problem ljubljanske bolnice sa prostorom prevazišao meru održivog. Na osnovu Zakona o bolnicama, ${ }^{1}$ pomenuta bolnica je od 1. aprila 1931. prešla u vlasništvo i pod upravu države, dok je pre toga bila pod upravom ljubljanske vlasti, odnosno banovine. Budžet bolnice je odobravan istovremeno sa državnim budžetom. Upravnik bolnice je bio dužan da raspolaže prihodima i rashodima odobrenim u budžetu bolnice. Kada se razmatraju odredbe Zakona, stiče se utisak da su primedbe o nedovoljnim sredstvima za finansiranje bolnice bile neosnovane. Država je, u suštini, izvršavala svoje zakonske obaveze. Pokazalo se, međutim, da je teško striktno poštovati zakonske odredbe budući da realan život donosi nepredvidive obaveze. Po Zakonu o bolnicama država je bila dužna da snosi bolničke troškove za svoje osoblje i službenike, kao i za one

\footnotetext{
1 „Zakon o bolnicah“, Uradni list kraljevske banske uprave dravske banovine, 1. 41, št. 1, (1930),
} 523-528. 
pacijente koji nisu mogli sami da plaćaju navedene troškove, niti je ove troškove mogao da im podmiri neko drugi ko je za to bio obavezan, i to u slučaju duševne bolesti, otvorene tuberkuloze ili venerične bolesti. ${ }^{2}$ Ovakvi stvarni troškovi bili su mnogo veći nego što je bilo predviđeno u budžetima (posebno u periodu ekonomske krize). Višak troškova je, dakle, pokrivala sama bolnica.

Po Zakonu o bolnicama, osnivanje i izgradnja novih bolnica bili su u nadležnosti države, banovine i gradskih opština sa preko 20.000 stanovnika. ${ }^{3} \mathrm{U}$ slučaju potrebe za proširenjem bolnice, u podeli troškova su morali da učestvuju svi oni koji su po zakonu bili dužni da osnivaju i grade bolnice, ${ }^{4}$ što znači država, banovina i gradske opštine. Uzimajući u obzir navedeni propis, ponovo je teško jednostrano pokazati prstom na državu tvrdeći da nije odobravala dovoljno sredstava. Potrebe za novim bolnicama, odnosno proširenjem postojećih, u celoj državi bile su velike. Izveštaji ministara za socijalnu politiku i narodno zdravlje podneti na sednicama Narodne skupštine Kraljevine Jugoslavije pokazuju da je država delovala u okviru zakonskih propisa i aktuelnih finansijskih mogućnosti. Predstavnici banovina, međutim, imali su u vidu samo svoju banovinu i tvrdili su da je kod njih najteže stanje. Mogli bismo reći da se radi o ,različitom razumevanju stvarnosti i različitim stvarnostima razumevanja, odnosno tumačenja činjenica“" 5

\section{Nedostatak prostora}

Navala pacijenata je postojala u svim bolnicama u Dravskoj banovini, ali najveća je bila upravo u Opštoj državnoj bolnici u Ljubljani, kao centralnoj bolnici. Bolnica je izgrađena krajem 19. veka sa 568 ležajeva, što je trebalo da bude dovoljno za približno 10.000 bolesnika godišnje. U periodu posle Prvog svetskog rata broj pacijenata je stalno rastao, za oko 15.000 godišnje, što je ostalo manje-više konstantno sve do 1927. godine. Potom je taj broj počeo naglo da raste, da bi 1937. dostigao 30.985 novoprimljenih pacijenata, a 1938. čak 31.419 pacijenata. ${ }^{6}$ Prostorni kapaciteti se nisu povećavali proporcionalno porastu broja pacijenata zato što nije bilo obezbeđeno dovoljno sredstava za veća proširenja bolnice. Istina, za vreme samoupravne vlasti i uz finansijsku pomoć Higijenskog zavoda 1927. godine je započet, a 1931. završen dodatni prostor za 10 postelja na infektivnom odeljenju. Ginekološko-porodiljsko odeljenje se sa školom babica preselilo 1923. godine u Azil za neizlečivo bolesne, koji je državna uprava kupila od Kranjske štedionice. Time je odeljenje postalo samostalan zavod pod nazivom Bolnica za ženske bolesti. Ispražnjeni prostori, u kojima su bila 64 kreveta, koristili su se delimično za dečje odeljenje, a deli-

\footnotetext{
${ }^{2}$ Isto.

${ }^{3}$ Isto.

${ }^{4}$ Isto.

5 Žarko Lazarević, Plasti prostora in časa: Iz gospodarske zgodovine Slovenije prve polovice 20. stoletja (Ljubljana: Inštitut za novejšo zgodovino, 2009), 278.

${ }^{6}$ Valentin Meršol, „Bolnišnice v Sloveniji“, u: Spominski zbornik Slovenije, urednici Jože Lavrič, Josip Mal, France Stele (Ljubljana: Jubilej, 1939), 492.
} 
mično za rendgenološki institut, dok je veći deo preuzeo Zavod za zdravstvenu zaštitu majke i deteta, koji je bio podređen Higijenskom zavodu, a ne bolnici. Nekada samostalna Bolnica za dečje bolesti sa približno 60 ležajeva postala je odeljenje opšte bolnice. $^{7}$

Na ovaj način dobijeni smeštajni kapaciteti nisu bili dovoljni, budući da je broj onih koji su pristizali u bolnicu bio u neprestanom porastu, zbog čega su u pojedine bolničke sobe stavljani novi stalni i privremeni ležajevi, tako da se broj ležajeva do početka 1935. povećao na 904 (u kvadraturi predviđenoj za 650 ležajeva). Uprava bolnice je postala rigoroznija pri prijemu pacijenata, ali to nije bilo rešenje. Uvedena je praksa da tri pacijenta dele dva ležaja ili dva bolesnika jedan ležaj. Da bi se postelje brže praznile, mnogi pacijenti su prerano otpuštani iz bolnice. Godine 1936. iz ljubljanske bolnice je prevremeno otpušteno $61 \%$ svih primljenih pacijenata (preko 18.000). ${ }^{8}$ To znači da je period bolničkog lečenja od prosečno 18 dana, ${ }^{9}$ koliko je tada bilo standardno, smanjen na približno 10 dana.

Načelnici pojedinih odeljenja bolnice često su upozoravali na uzroke i iznosili moguća rešenja za nedostatak prostora centralne ljubljanske bolnice, $\mathrm{i}$ to pre svega u glavnom medicinskom časopisu Zdravniški vestnik. ${ }^{10}$ Članci u časopisu pokazuju da su u to vreme glavne bolesti bile tuberkuloza i rak, pri čemu je smrtnost zbog raka bila u porastu, a broj smrtnih slučajeva zbog tuberkuloze u laganom, ali stalnom opadanju. ${ }^{11}$ To je bio rezultat sistematske borbe protiv tuberkuloze, dok u slučaju malignih bolesti takav pristup još nije postojao. Posledično, nije bilo ni svesti među ljudima o preventivnim merama u sprečavanju malignih bolesti. Zbog neznanja čak 2/3 pacijenata prekasno je stizalo na operaciju ili su pak posle operacije duže vreme bili bez kontrole. ${ }^{12}$

Stavove načelnici pojedinih odeljenja bolnice o uzrocima preopterećenja bolnice i mogućim rešenjima možemo sažeti u sledeće zaključke. Posle Prvog svetskog rata broj stanovnika se povećao, a istovremeno i njihova svest o značaju bolničkog lečenja. Još u 19. veku ljudi su se plašili bolnica, budući da je vladalo uverenje da u njima svi umiru. U stvari, smrtnost je bila veća zbog prekasnog dolaska pacijenta u bolnicu (samo najteže bolesni su dolazili u bolnicu) i odsustva ,,asepse“, ${ }^{13}$ zbog čega su se posle operacije gotovo sve rane inficirale.

\footnotetext{
${ }^{7}$ Isto, 492-493.

${ }^{8}$ Isto, 494.

${ }^{9}$ Isto. Po tadašnjim međunarodnim propisima, smatralo se da bolnica ima normalno popunjene kapacitete ukoliko je svaki pacijent prosečno mogao boraviti u njoj barem 18 dana i ako je, pored toga, u bolnici bilo stalno na raspolaganju 30\% praznih ležajeva.

${ }^{10}$ Građa fonda Opšte državne bolnice u Ljubljani u Arhivu Republike Slovenije (ARS, fond 425, Obča državna bolnica v Ljubljani (1918-1945), obim: 146 fascikli, 359 knjiga) ne omogućava dublji uvid u prostorni problem bolnice budući da je sačinjavaju samo lični podaci i dijagnoze pacijenata, iz čega bi bilo moguće napraviti analizu najčešćih bolesti i njihove učestalosti. Pošto zaštita ličnih podataka ne dozvoljava ovakvu analizu, naš istraživački rad je prvenstveno bio orijentisan na literaturu.

${ }^{11}$ Stanko Černelč, ,Rak v Dravski banovini v luči statistike“, Zdravniški vestnik: strokovno glasilo zdravništva v dravski banovini, 1. 3, št. 9, (1937), 106.

${ }^{12}$ Isto, 107.

${ }^{13}$ Stanje potpunog odsustva bilo kakvog oblika mikroorganizama.
} 
Bitno je i to što su bolnice bile namenjene prvenstveno siromašnim građanima dok su imućnije lečili porodični lekari, koji su ih posećivali u njihovim kućama. Posebno posle Prvog svetskog rata, dakle, poverenje u bolnice se povećalo, budući da je relativno malo ljudi umiralo u njima. Većina njih se vratila kući izlečena ili barem u boljem stanju. Kad govorimo o poverenju u sistem, ne možemo zaobići bolje higijenske uslove koji su sprečili pojavu sepse i druge infekcije. ${ }^{14}$ Međutim, ako uzmemo uzorak ljubljanskog porodilišta, koje je do 1923. godine bilo odeljenje centralne bolnice, vidimo da se nakon Prvog svetskog rata povećao broj rođenih. Godine 1914. rođena su 543 deteta, 1919. njih 631, dok je 1920. godine bilo 813 novorođenih. ${ }^{15}$ Usled nedostatka stambenih uslova i loših socijalnih prilika, sve više žena koje su bile socijalno ugrožene rađale su u porodilištu, odnosno sve manje kod kuće. ${ }^{16}$

Razvoj moderne medicine doveo je do toga da su za dijagnozu bolesti i lečenje bili potrebni skupi aparati (npr. rendgen), laboratorije i posebno kvalifikovano osoblje. Sve to su mogle ponuditi samo velike i prvoklasno uređene bolnice. Ekonomska kriza je takođe bila važan momenat u podizanju svesti ljudi o značaju bolničkog lečenja. Nedostatak kvalitetne hrane kod kuće, loši stambeni uslovi, nemogućnost pravilne nege u kućnim uslovima, nestašica finansijskih sredstava za često skupo lečenje - sve je to doprinelo saznanju da je lečenje u bolnici često najjeftinije. Oni koji su bili u slabom materijalnom stanju, tešili su se u ovom smislu: „Ako sam ne budem mogao da plaćam troškove nege, plaćaće ih opština ili država“. Mnogo ljudi je bilo osigurano i kod raznih blagajni, koje su nastojale da se njihovi pacijenti leče na najuspešniji način i da što pre ozdrave. Zbog toga su svoje bolesne članove slale u bolnicu. ${ }^{17}$

Ljubljanska bolnica je izgrađena krajem 19. veka, za uslove kakvi su tada vladali u Ljubljani koja je imala oko 20.000 stanovnika. Broj stanovnika je tokom vremena stalno rastao. Krajem dvadesetih godina 20. veka Ljubljana je postala upravno središte Dravske banovine, zbog čega su u bolnicu upućivani pacijenti iz cele Slovenije. Naime, u periodu Austro-Ugarske monarhije pacijenti su takođe odlazili u Grac, Klagenfurt, Trst, Beč. Ljubljanska bolnica je jedina u Dravskoj banovini imala ortopedsko i urološko odeljenje, koja su delovala u okviru hirurškog odeljenja. ${ }^{18}$ Najopterećenija su bila upravo hirurško i interno odeljenje, koje je bilo najveće nakon hirurškog. ${ }^{19} \mathrm{O}$ opterećenju hirurškog odeljenja svedoči podatak da je 1895. godine broj ležajeva iznosio 147, a tokom 1933. u istim prostorima bilo je 217 ležajeva. Na njima je često ležalo do 235

${ }^{14}$ Peter Borisov, Od ranocelništva do začetkov znanstvene kirurgije na Slovenskem (Ljubljana: Slovenska akademija znanosti in umetnosti, 1977), 256.

15 Peter Borisov, Ginekologija na Slovenskem od nastanka do 80. let 20. stoletja (Ljubljana: Slovenska akademija znanosti in umetnosti, 1995), 175.

${ }^{16}$ Isto.

${ }^{17}$ Valentin Meršol, „O ljubljanski bolnišnici“, Zdravniški vestnik: strokovno glasilo zdravništva v dravski banovini, 1. 2, št. 8, (1936), 2, 8, 75.

18 Mirko Černič, „Ljubljanski kirurški oddelek, sepsa spomladi 1933 in še kaj“, Zdravniški vestnik: strokovno glasilo zdravništva v dravski banovini, 1. 5, št. 11, (1933), 381-382.

19 „Trpljenje v številkah“, Slovenec: političen list za slovenski narod, 16. 1. 1931, 8. 
pacijenata, i to po dva pacijenta $u$ istom krevetu. Hirurškom odeljenju su nedostajali dnevni prostori za pokretne pacijente, prostor za pacijente sa otvorenom tuberkulozom pluća, poseban ambulantni prostor, adekvatne sanitarije, a i operacione sale nisu bile u skladu sa zahtevima moderne medicine. ${ }^{20}$ Odeljenju je bila potrebna rekonstrukcija, u skladu sa zahtevima savremene hirurgije.

Mišljenja struke o rešenjima kojim bi se prevazišao nedostatak prostora bila su raznolika. Postojalo je mnoštvo predloga, ali se nije došlo do generalnog rešenja. Prostorni kapaciteti bolnica su bili svedržavni problem, koji je najkonkretnije pokušao da reši ministar za socijalnu politiku i narodno zdravlje Dragiša Cvetković (o tome nešto kasnije). Vratimo se na predloge slovenačkih lekara za rešavanje prostornih problema centralne ljubljanske bolnice. Struka je osnovni problem videla u nedostatku mesnih bolnica, koje bi rasteretile ljubljansku. Pod mesnim bolnicama su podrazumevane ustanove sa internim i hirurškim odeljenjem, svako sa 30-40 ležajeva. U takvim bolnicama mogli su se lečiti bolesnici sa kilom, zapaljenjem slepog creva ili svakodnevnim povredama, koji su inače opterećivali hirurško odeljenje ljubljanske opšte bolnice. Zbog prevelikog opterećenja odeljenja dolazilo je do smetnji u radu i nepotrebnih nesreća. Od 1923. do 1933. godine broj primljenih pacijenata se povećao za $138 \%$, a broj operisanih za $512 \% .^{21}$

Usled udaljenosti ljubljanske bolnice, mnogi pacijenti stizali su prekasno (sa već razvijenim rakom kože, komplikovanom upalom slepog creva i drugim bolestima). Poseban problem bio je nedostatak bolnica u južnom delu Dravske banovine i u Gorenjskoj. U Gorenjskoj je na Javorniku postojala privatna bolnica Bratovske skladnice Kranjskog industrijskog društva sa internim i infektivnim odeljenjem, ali je ona bila samo za članove Bratovske skladnice i bez hirurškog odeljenja. Južno od Save postojale su samo tri bolnice: pored ljubljanske, bolnice u Novom Mestu i Krškom. Severno od Save bilo je čak sedam bolnica: u Mariboru, Celju, Slovenj Gradecu, Ptuju, Ormožu, Murskoj Soboti i Brežicama. ${ }^{22}$

Struka je bila svesna da finansijska sredstva ne omogućavaju izgradnju nove moderne bolnice $\mathrm{i}$ da je potrebno razmišljati o proširenju postojeće zgrade i rasterećenju opšte bolnice tamo gde je to moguće. Stavovi u vezi sa načinom rasterećenja, međutim, bili su različiti. Pojedini lekari su bili veoma rigorozni, smatrajući da je potrebno uvesti princip po kojem je bolnica rezervisana samo za izlečive bolesti, prvenstveno za akutne bolesti i slučajeve kod kojih je ugrožen život. Po njihovom mišljenju trebalo je povećati troškove za bolničko lečenje, uvesti detaljnu reviziju uverenja o lošem materijalnom stanju i kontrolu smanjivanja ili otpisivanja troškova lečenja i pooštriti indikacije za prijem u bolnicu. Drugi lekari se sa time nisu slagali, polazeći od stanovišta da naknade za lečenje jedva mogu pokriti troškove nege onog pacijenta koji ih plaća u celo-

\footnotetext{
${ }^{20}$ M. Černič, „Ljubljanski kirurški oddelek, sepsa spomladi 1933 in še kaj“, Zdravniški vestnik: strokovno glasilo zdravništva v dravski banovini, 1. 5, št. 11, (1933), 382-383.

${ }^{21}$ Mirko Černič, „Ljubljanski kirurški oddelek, sepsa spomladi 1933 in še kaj“, Zdravniški vestnik: strokovno glasilo zdravništva v dravski banovini, 1. 6, št. 1, (1934), 24.

${ }^{22}$ Isto, 25.
} 
sti, a kamoli za članove svih vrsta bolničkih blagajni. Bolnice, međutim, nisu profitabilne ustanove, već temelj i glavno oruđe zdravstvene i socijalne politike, posebno u periodu ekonomske krize, koja je bila zahvatila sva mesta i domaćinstva. U vezi sa molbama za otpis ili sniženje troškova lečenja, smatrali su da je postupak provere jasan i pouzdan. Bolnička uprava je za svaku takvu molbu morala sprovesti opsežnu istragu, a uverenja o lošem materijalnom stanju nisu smela biti od odlučujućeg značaja pri procenjivanju imovinskog stanja. Samo na osnovu tih uverenja nikome se ne bi smeli otpisati ili sniziti troškovi za bolničko lečenje. Uverenje o lošem materijalnom stanju je bilo dovoljno samo za dobijanje besplatnog ambulantnog lečenja. U vezi sa smernicama za prijem pacijenata, Zakon o bolnicama iz 1930. bio je u izvesnoj meri neprecizan, budući da je određivao da u zavod mora biti primljen svako kome je bilo preko potrebno bolničko lečenje. ${ }^{23} \mathrm{U}$ zavisnosti od socijalnih okolnosti, ovakvo uputstvo se moglo tumačiti u znatno širem smislu ili pak znatno suziti.

Postojali su i predlozi o osnivanju socijalne službe bolnica, koja je u inostranstvu već bila uvedena. Bolnička socijalna služba je ostvarivala vezu između pacijenta i njegove porodice i omogućavala da se skrati period lečenja u bolnici. U socijalnoj zaštiti izvan bolnice (tzv. „otvorena socijalna nega“), koja je morala biti u neposrednoj vezi sa bolničkom negom, pacijentu se jeftinije, a uprkos tome adekvatnije njegovom stanju pomagalo pri izlečenju u kućnim uslovima. Pomenuta služba se brinula o tome da pacijent posle odlaska iz bolnice ne bude zapostavljen ili da ne ugrožava svoje ukućane. Ovakvu instituciju je u Kraljevini Jugoslaviji vatreno zagovarao dr Svetislav Stefanović (tadašnji predsednik Srpskog lekarskog društva), koji je već 1929. godine u Srpskom arhivu za celokupno lekarstvo napisao članak pod nazivom „O bolnicama, njihovoj socijalnoj ulozi i službi““. ${ }^{24}$

Struka je, ipak, bila jedinstvena u mišljenju da je problem ljubljanske bolnice potrebno rešavati sveobuhvatno i podsticati saradnju države, banske uprave i grada Ljubljane u stvaranju jedinstvenog plana. Svaka pojedinačna akcija koja ne bi sveobuhvatno uzela u obzir problem ljubljanske bolnice i sve njene potrebe, bila bi neadekvatna.

Problemom ljubljanske bolnice bavila se i banska uprava na svojim sednicama. Uzroke prostornog, finansijskog, kadrovskog i higijenskog problema centralne ljubljanske bolnice i uopšte bolnica u zemlji predstavio je ban Marko Natlačen u ekspozeu na jednoj od poslednjih banovinskih sednica 17. februara 1941. Natlačen je komentarisao i zdravstvene uslove u zemlji, istakavši da se ni državnoj ni pokrajinskoj upravi ne može prebaciti da se nisu dovoljno interesovale za zdravlje ljudi tokom dvadeset godina svog delovanja. Bio je uveren da je mnogo toga urađeno i istakao je da su se izdaci u tu svrhu povećali, posebno u poslednje vreme. Istovremeno je otvoreno priznao da postignuti

${ }^{23}$ „Zakon o bolnicah“, Uradni list kraljevske banske uprave dravske banovine, 1. 41, št. 1, (1930), $523-528$.

24 Alojz Zalokar, „Pomanjkanje postelj in socialna služba v naših bolnišnicah“, Zdravniški vestnik: strokovno glasilo zdravništva v dravski banovini, 1. 8, št. 5, (1936), 211-214. 
uspesi nisu u skladu sa naporima koji su bili uloženi. Posebno nije bilo uspeha u rešavanju pitanja bolnica. Dok su se banovinske bolnice generalno držale na dostojnom nivou, centralna državna bolnica $u$ Ljubljani nalazila se $u$ veoma lošem stanju i nije držala korak sa zahtevima moderne medicine. ${ }^{25}$ Postojalo je više uzroka takvom stanju. Zdravstvena politika u zemlji je, po mišljenju bana, od samog početka postavljena na pogrešnim temeljima. Zdravstvena služba je bila zasnovana na dva odvojena koloseka. Na prvom je bila preventivna zdravstvena služba, koja je formirana uz velike finansijske žrtve sa zadatkom da aktivno sprovodi zdravstvenu službu, to jest da budi svest ljudi o preventivnim metodama u sprečavanju bolesti. Ban Natlačena je smatrao da, uprkos velikom trudu i velikim finansijskim ulaganjima, preventivne zdravstvene ustanove nisu dorasle svom zadatku, budući da bez saradnje sa ustanovama kurativne medicine nisu mogle obezbediti uslove za uspešno delovanje. Posledica visokih izdataka za preventivne ustanove je bila u tome što su ustanove kurativne medicine (bolnice) bile uskraćene. U tom sistemu sa dva koloseka bolnicama je bila namenjena podređena uloga - isključivo lečenje bolesti. ${ }^{26}$

Sa ovim problemima suočavale su se, osim centralne ljubljanske bolnice, i druge bolnice u zajedničkoj državi. U Kraljevini je 1931. godine bilo oko 27.000 bolničkih kreveta, od čega oko 5.000 u Dravskoj banovini (od toga oko 3.200 za opšte bolesti). U celoj zemlji su prosečno dolazila 2 kreveta na 1.000 stanovnika, a u Dravskoj banovini oko 4 na 1.000 stanovnika, uzimajući u obzir sve krevete. ${ }^{27}$

Osim bolnica u Dravskoj banovini, preopterećene su bile bolnice u Savskoj i Dunavskoj banovini, kao i u Beogradu. U drugim banovinama broj bolesnika je bio manji. U našem istraživanju nismo naišli na konkretne razloge, ali može se zaključiti da su manjem opterećenju tih bolnica doprineli nedostatak svesti kod ljudi, još uvek prisutno poverenje u ,kućno lečenje“ koje je navodno bilo „,bolje“", kao i loše saobraćajne veze unutrašnjosti sa centrima u kojima su se bolnice nalazile. Bolji uvid u stanje po pojedinim bolnicama pruža tabela 1 , sa podacima iz 1931. godine.

Tabela 1: Stanje u pojedinim bolnicama $1931 .^{28}$

\begin{tabular}{|c|c|c|c|}
\hline Bolnica & Broj kreveta & $\begin{array}{c}\text { Broj pacijenata } \\
\text { tokom godine }\end{array}$ & $\begin{array}{c}\text { Broj pacijenata na jedan } \\
\text { krevet tokom godine }\end{array}$ \\
\hline Opšta državna bolnica Ljubljana & 860 & 21.543 & 25 \\
\hline Opšta bolnica Maribor & 544 & 9.020 & 17 \\
\hline Državna bolnica Sarajevo & 1.027 & 8.601 & 8 \\
\hline Opšta državna bolnica Beograd & oko 1.500 & 19.140 & 13 \\
\hline Zakladna bolnica Zagreb & oko 500 & 6.775 & 14 \\
\hline Državna bolnica Skoplje & 238 & 3.150 & 13 \\
\hline
\end{tabular}

${ }^{25}$ Dunja Dobaja, ,Socialna in zdravstvena problematika v obdobju Ljubljanske oblasti in Dravske banovine“, u: Marko Natlačen (1886-1942) v zgodovinskem dogajanju, urednik Zdenko Čepič (Ljubljana: Inštitut za novejšo zgodovino, 2012), 153-154.

${ }^{26}$ Arhiv Republike Slovenije (ARS), fond 77, Banski savet Dravske banovine, fascikla 15, Stenografski zapisnik V. sednice XIII. redovnog zasedanja banskog saveta dravske banovine u Ljubljani dana 21. 2. 1941.

${ }^{27}$ V. Meršol, O ljubljanski bolnišnici, 76.

${ }^{28}$ Isto. 
Problem bolnica, odnosno raskorak između kurativne i preventivne medicine, razmatran je i na sednicama Narodne skupštine i Senata Kraljevine Jugoslavije. Kod slovenačkih predstavnika se u vezi sa ovim pitanjem ne može primetiti odlučniji nastup i predlaganje konkretnih rešenja, kakva bismo mogli da očekujemo. Inače, bili su svesni neophodnosti rešavanja problema i u intervalima su upozoravali na to, ali nisu bili tako prodorni kao predstavnici drugih banovina. ${ }^{29}$ Ukratko, nedostaju njihovi konkretni predlozi za rešavanje problema ljubljanske bolnice i za pitanje bolnica u Kraljevini Jugoslaviji generalno.

\section{Razmatranje pitanja bolnica, odnosno kurativne i preventivne medicine, na sednicama Narodne skupštine Kraljevine Jugoslavije i Senata Kraljevine Jugoslavije}

Na sednicama Narodne skupštine i Senata Kraljevine Jugoslavije isticana je činjenica da preventivna i kurativna medicina (lečenje pacijenata) ne idu u korak jedna sa drugom. Preventivna medicina je bila protežirana, ali uprkos tome nije pokazala zadovoljavajuće rezultate. Posle Prvog svetskog rata preventivna medicina je postala aktuelna, dok je kurativna medicina, odnosno bolnice, zanemarivana. Budući da je jedna od posledica Prvog svetskog rata bio veliki broj osoba sa hroničnim bolestima, prevashodno su bile potrebne bolnice, lečilišta, sanatorijumi itd. Pacijentima je pre svega bilo potrebno lečenje, pri čemu ne možemo smetnuti s uma ni higijenu, odnosno preventivu. ${ }^{30}$

Nedostatak prostora u bolnicama je bio opšti problem. U raspravama na sednicama Narodne skupštine i Senata učesnici su govorili o bolnicama generalno i nisu razlikovali državne od banovinskih bolnica, iz čega se može zaključiti da su se obe vrste bolnica suočavale sa sličnim problemima. Ipak, zapisnici sa sednica pokazuju da su banovinske bolnice u Dravskoj banovini bile na višem nivou nego centralna državna bolnica u Ljubljani.

Na sednicama su kritikovani neadekvatni uslovi za rad lekara u bolnicama, kao i loša opremljenost bolnica lekovima i bolničkom opremom. ${ }^{31}$ Upozoravano je na besmislenost osnivanja manjih bolnica, budući da su troškovi

29 „VI. redovni sastanak Narodne skupštine Kraljevine Jugoslavije“, Stenografske beleške Narodne skupštine Kraljevine Jugoslavije, god. 4, br. 2, (1935), 87; „XXXV. redovni sastanak Narodne skupštine Kraljevine Jugoslavije“, Stenografske beleške Narodne skupštine Kraljevine Jugoslavije, god. 6, br. 2, (1937), 1216.

${ }^{30}$ „XVI. redovni sastanak Senata Kraljevine Jugoslavije“, Stenografske beleške Senata Kraljevine Jugoslavije, god. 1, br. 20, (1932), 294. Do Prvog svetskog rata preventivna medicina, prvenstveno u pogledu institucija, bila je zanemarena oblast u Srbiji, kao i u zemljama koje su ušle u sastav Kraljevine SHS. Poznate su, međutim, užasne posledice epidemija zaraznih bolesti tokom rata. O tome više: Zvonka Zupanič Slavec, Razvoj javnega zdravstva na Slovenskem med prvo in drugo svetovno vojno in njegov utemeljitelj dr. Ivo Pirc (Ljubljana: Inštitut za varovanje zdravja RS, 2005).

${ }^{31}$ Navodimo primer grada Požarevca u Srbiji, koji nije bio usamljen. U gradu su postojala četiri hirurga, ali je u bolnici za operacije na raspolaganju bila samo jedna mala soba, gde je mogao da radi samo jedan hirurg. U: „XVI. redovni sastanak Senata Kraljevine Jugoslavije“, Stenografske beleške Senata Kraljevine Jugoslavije, god. 1, br. 20, (1932), 294. 
njihovog održavanja bili visoki, pri čemu takve bolnice nisu ispunjavale očekivanja. Postojali su predlozi za osnivanje ambulanti, koje bi nudile prvu medicinsku pomoć i besplatan pregled pacijenata.

Detaljnije se, uz navođenje konkretnih rešenja, pitanju kurativne i preventivne medicine, odnosno pitanju bolnica, posvetio ministar za socijalnu politiku i narodno zdravlje Dragiša Cvetković, ${ }^{32}$ budući da su mu povoljnije finansijske mogućnosti u drugoj polovini tridesetih godina to omogućivale. ${ }^{33} \mathrm{Na}$ sednici Narodne skupštine Kraljevine Jugoslavije početkom marta 1937. u opsežnom ekspozeu istakao je da je higijenska služba (preventivna medicina) u zemlji prilično dobro i sistematično organizovana, zbog čega daje pozitivne rezultate na terenu. U poređenju sa njom, bolnička služba (kurativna medicina) nije na zavidnom nivou. Organizacija bolnica nije odgovarala potrebama. Umesto formiranja velikih i moćnih bolnica po ugledu na bolnice u zapadnoj Evropi, sa kvalitetnim zdravstvenim kadrom i savremenom tehničkom opremom, u jugoslovenskoj državi su se osnivale bolnice u skoro svakom mestu. Ove bolnice nisu mogle doseći adekvatan nivo ni po stručnoj kompetenciji ni po tehničkoj opremljenosti. Umesto toga u manjim mestima trebalo bi formirati posebne ambulante, koje bi pacijente u slučaju potrebe upućivale u bolnice u većim gradovima. Uzroke nedostatka potrebnog broja $k$ reveta ${ }^{34} \mathrm{u}$ bolnicama video je $\mathrm{u}$

${ }^{32}$ Dragiša Cvetković (1893-1969), novinar, publicista, narodni poslanik, jedan od osnivača Jugoslovenske radikalne zajednice. U obe vlade Milana Stojadinovića bio je ministar socijalne politike i narodnog zdravlja (22. decembar 1935-5. februar 1939), a u kraćim periodima je bio zastupnik ministra pravde i fizičkog vaspitanja. Podnošenjem ostavke na ministarsko mesto, sa još četvoricom ministara, doveo je do pada vlade Milana Stojadinovića u februaru 1939. Dva dana nakon toga poveren mu je mandat za sastav nove vlade. U prvoj vladi koju je obrazovao 5. februara 1939. preuzeo je i portfelj ministra unutrašnjih poslova. Posle sporazuma sa liderom Hrvatske seljačke stranke dr Vladkom Mačekom 26. avgusta 1939. formirao je vladu Cvetković-Maček i zadržao mesto ministra unutrašnjih poslova. Novembra 1939. imenovan je za senatora. Tokom februara 1941. vodio je pregovore sa vođom Trećeg rajha Adolfom Hitlerom i ministrom inostranih poslova Joakimom fon Ribentropom u Fušlu i Berghofu. Zajedno sa ministrom inostranih poslova Aleksandrom Cincar-Markovićem potpisao je Protokol o pristupanju Jugoslavije Trojnom paktu u dvorcu Belvedere u Beču 25. marta 1941. Dva dana kasnije njegova vlada je oborena u puču, a on je uhapšen i zadržan sve dok nije potpisao ostavku na mesto predsednika Ministarskog saveta. Tokom Drugog svetskog rata odbio je da sarađuje sa okupatorom, a posle rata je osuđen kao ratni zločinac i živeo je u emigraciji. M. Gulić, „Cvetković Dragiša“, u: Senatori Kraljevine Jugoslavije: Biografski leksikon, urednici Momčilo Pavlović, Nebojša Stambolija, Milan Gulić (Beograd: Institut za savremenu istoriju, 2016), 71-73.

${ }^{33}$ Njegov prethodnik Ivan Pucelj se branio od primedbi u vezi sa problematikom bolnica u zemlji objašnjenjem da mu budžetska sredstva omogućavaju sprovođenje samo osnovnih socijalnih zadataka. U: „XVIII. redovni sastanak Senata Kraljevine Jugoslavije“, Stenografske beleške Senata Kraljevine Jugoslavije, god. 3, br. 2, (1934), 247-248.

${ }^{34}$ Ministar za socijalnu politiku i narodno zdravlje Dragiša Cvetković navodi podatak za 1937. godinu, kada su u zemlji postojala ukupno 21.162 bolnička kreveta, pri čemu su tu uračunate sve bolnice (državne, banovinske, osiguravajućih društava i privatne). S obzirom na broj stanovnika u državi i zdravstvene uslove, uzimajući u obzir standarde u drugim evropskim zemljama, za opšte bolesti bi bilo potrebno 70.000 bolničkih kreveta, a za specijalne bolnice, s obzirom na broj obolelih, ukupno 85.000 bolničkih kreveta. U: „XXXV. redovni sastanak Narodne skupštine Kraljevine Jugoslavije“, Stenografske beleške Narodne skupštine Kraljevine Jugoslavije, god. 6, br. 2, (1937), 1159-1160. 
nedovoljnoj organizovanosti bolnica i velikom broju manjih bolnica, koje su zahtevale znatna finansijska sredstva, ali nisu bile kadre da se nose sa savremenim potrebama lečenja i stručne kompetencije.

Za reorganizaciju bolničke službe predlagao je nov, savremen zakon o bolnicama, koji bi odgovarao njenim potrebama i ojačao ulogu bolnica. Zakon o bolnicama iz 1930. godine, po tvrđenju ministra za socijalnu politiku i narodno zdravlje, nije omogućavao da se dostigne potreban broj bolničkih kreveta za opšte bolesti, a još manje da se osnivaju neophodne specijalne bolnice. ${ }^{35}$

Predlog pomenutog zakona je naišao na neprihvatanje lekarskih komora i samih lekara, zbog čega je ministar za socijalnu politiku i narodno zdravlje Dragiša Cvetković, na sednici Narodne skupštine početkom marta $1938,{ }^{36}$ predlagao Savezu lekarskih komora u Beogradu da do 15. aprila 1938. formiraju svoj predlog zakona. Kompromisima i dogovorima trebalo je formulisati zakon koji bi reformisao bolničku službu i stvarno odgovarao vitalnim interesima i potrebama ljudi.

Arhivska građa Lekarske komore (zbornice) za Dravsku banovinu pokazuje da je bilo mnogo razgovora o oblikovanju novog zakona o bolnicama, koji bi sveobuhvatno zahvatio problem i ponudio preko potrebna rešenja. ${ }^{37} \mathrm{Sa}-$ činjeno je više nacrta zakona, koji su donosili poboljšanje samo u određenim segmentima. Zakon o bolnicama iz 1930. godine kritikovan je odmah posle usvajanja i pojavila su se zalaganja za novi zakon. Lekarska komora za Dravsku banovinu odazvala se već 1933. godine pozivu Saveza lekarskih komora u Beogradu da definiše svoje stanovište prema novom zakonu o bolnicama i dostavi svoje predloge. ${ }^{38}$ Komora je pošla od stava da se ne sme uzimati u obzir interes pojedinih kategorija lekara, nego interes svih lekara. Potrebna je, dakle, saradnja između lekara. Odsustvo te saradnje je, navodno, bio jedan od suštinskih uzroka lošeg stanja u bolnicama. Tadašnji upravnik državne bolnice u Ljubljani, dr Franc Gerlovič, sazvao je sednicu načelnika pojedinih odeljenja radi rasprave o predlozima novog zakona o bolnicama. ${ }^{39}$ Predlozi su bili usmereni pre svega na to da se centralna ljubljanska bolnica vrati u vlasništvo i pod upravu banovine. Bolnice u zemlji trebalo je postaviti na potpuno ekonomsku osnovu, što znači da se finansiraju i razvijaju isključivo iz svojih sredstava. Da bi to bilo moguće, bolnice bi morale dobijati realne troškove lečenja za svakog pacijenta. Troškovi nege bi bili isti za sve pacijente, bez obzira na to ko je finansirao njihovo lečenje. Visinu troškova trebalo je da određuju banske uprave u onom opsegu koji

35 „XXXV. redovni sastanak Narodne skupštine Kraljevine Jugoslavije“, Stenografske beleške Narodne skupštine Kraljevine Jugoslavije, god. 6, br. 2, (1937), 1159-1160.

36 „XXXII. redovni sastanak Narodne skupštine Kraljevine Jugoslavije“, Stenografske beleške Narodne skupštine Kraljevine Jugoslavije, god. 7, br. 3, (1938), 841.

${ }^{37}$ ARS, fond 1218, Lekarska zbornica za Sloveniju, fascikla 1, godina 1938, Zapisnik XV. redovne godišnje skupštine Lekarske zbornice koja je održana dana 6. 3. 1938, Izveštaj predsedništva i upravnog odbora.

${ }^{38}$ Isto, fascikla 2, godina 1931, Zapisnik sednice upravnog odbora lekarske zbornice za dravsku banovinu od dana 10. 6. 1933 .

${ }^{39}$ Isto. 
bi omogućavao da se bolnice mogu samostalno razvijati. Bolnice bi u ovom smislu morale same da se brinu za proširenje svojih prostornih kapaciteta. U tu svrhu one bi određen iznos troškova lečenja ulagale u građevinski fond, kojim bi same upravljale pod nadzorom i propisima banske uprave. ${ }^{40}$

Tokom 1938. godine Lekarska komora za Dravsku banovinu ponovno se odazvala pozivu Saveza lekarskih komora o definisanju predloga novog zakona. U tu svrhu osnovan je tročlani odbor koji je sastavio novi nacrt. ${ }^{41} \mathrm{U}$ izvoru nema sadržaja nacrta, ali možemo zaključiti da su glavne smernice bile slične prvom nacrtu iz 1933. godine.

Ministarstvo je pod rukovodstvom Miloja Rajakovića ${ }^{42}$ nastavilo započeti posao Dragiše Cvetkovića, nastojeći da se zdravstvena politika neprestano razvija i napreduje u skladu sa potrebama naroda. Takvo koordinisano delovanje je trebalo da bude put do konačnog cilja - unapređenja narodnog zdravlja i sveobuhvatne zdravstvene zaštite. ${ }^{43}$

Ministarstvo je konstatovalo da, uprkos uloženim naporima i uspesima, stanje bolničke službe i dalje nije zadovoljavajuće. Osnovni problemi su bili nedovoljan broj bolnica i kapaciteta u njima, nepravilan teritorijalni raspored i slaba opremljenost bolnica. Za rešenje tih problema već je u vreme ministrovanja Dragiše Cvetkovića predlagana uredba sa snagom zakona, koja je predviđala osnivanje Narodnog sanitetskog fonda. Sprovođenjem te ideje trebalo je poboljšati uslove ne samo u bolničkoj službi, već bi se time obezbedila i finansijska sredstva za održavanje postojećih i osnivanje novih bolnica. ${ }^{44}$ Ministarstvo je pod rukovodstvom ministra Rajakovića osnovalo inspekcijsku službu u cilju prikupljanja podataka o uslovima u bolnicama. Ovi podaci bi činili osnovu za donošenje planova o osnivanju novih bolnica i njihovoj unutrašnjoj uređenosti, za poboljšanje organizacije rada u postojećim i novim bolnicama, kao i donošenje efikasnih zakonskih propisa koji bi bili u skladu sa stvarnim potrebama.

U drugoj polovini 30-ih godina država, odnosno Ministarstvo za socijalnu politiku i narodno zdravlje, ponudila je konkretna rešenja za problem bolnica. Za ostvarivanje promena u praksi, međutim, bilo je potrebno vreme, koje Kraljevina Jugoslavija više nije imala zbog izbijanja Drugog svetskog rata.

\footnotetext{
${ }^{40}$ Isto.

${ }^{41}$ ARS, 1218-1-1938.

${ }^{42}$ Miloje Rajaković (1895-1945), diplomata, novinar, privrednik, narodni poslanik, jedan od osnivača Jugoslovenske radikalne zajednice, senator. Početkom 1939. ušao je u kabinet Dragiše Cvetkovića kao ministar socijalne politike i narodnog zdravlja. Posle Drugog svetskog rata je streljan. Nemanja Dević, „Rajaković Miloje“, u: Senatori Kraljevine Jugoslavije: Biografski leksikon, 253.

43 „Ekspoze Ministra socijalne politike i narodnog zdravlja u narodnoj skupštini o budžetu Ministarstva za 1939-1940 godinu“, Socijalni arhiv, god. 5, br. 1-2, (1939), 5.

${ }^{44}$ Isto.
} 


\section{Zaključak}

Problem prostora Opšte državne bolnice u Ljubljani u periodu između dva svetska rata nije bio rešen, i pored mnoštva predloga i razgovora o toj temi. Do izgradnje novog zavoda ili značajnijih proširenja postojećih kapaciteta nije došlo zbog oskudice finansijskih sredstava. Uprkos tome, korišćeni resursi ukazuju na to da je pacijentima bila posvećena velika pažnja i da su dobijali kvalitetnu negu tokom svog lečenja.

Problem prostornih kapaciteta ljubljanske bolnice bio je rezultat opšte politike države, koja je ubrzo po donošenju Zakona o bolnicama 1930. uvidela da zakon u praksi ne funkcioniše. Već pri njegovom stupanju na snagu pojavila su se zalaganja za novi zakon koji bi sveobuhvatno rešio ovu problematiku. Zakon o bolnicama u suštini nije bio loš, ali je mnoštvo različitih interesa, posebno u razdoblju ekonomske krize i nedostataka finansijskih sredstava, onemogućavalo da zakon bude ostvaren u praksi. U periodu ministrovanja Dragiše Cvetkovića uspostavljen je izvestan red i pojavili su se konkretni predlozi za rešavanje opšteg problema bolnica u zemlji. Vreme bi, verovatno, donelo pozitivne rezultate i postavilo stvari na svoje mesto, da Drugi svetski rat nije zaustavio ovaj proces. 


\section{REFERENCE}

- Borisov, Peter. Od ranocelništva do začetkov znanstvene kirurgije na Slovenskem. Ljubljana: Slovenska akademija znanosti in umetnosti, 1977.

- Borisov, Peter. Ginekologija na Slovenskem od nastanka do 80. let 20. stoletja. Ljubljana: Slovenska akademija znanosti in umetnosti, 1995.

- Černič, Mirko. „Ljubljanski kirurški oddelek, sepsa spomladi 1933 in še kaj““. Zdravniški vestnik: strokovno glasilo zdravništva $v$ dravski banovini, 1. 5, št. 11, (1933), 381-386.

- Černič, Mirko. „Ljubljanski kirurški oddelek, sepsa spomladi 1933 in še kaj“. Zdravniški vestnik: strokovno glasilo zdravništva v dravski banovini, 1. 6, št. 1, (1934), 24-29.

- Černelč, Stanko. „Rak v Dravski banovini v luči statistike“. Zdravniški vestnik: strokovno glasilo zdravništva v dravski banovini, 1. 3, št. 9, (1937), 103-108.

- Dević, Nemanja. „Rajaković Miloje“. U: Senatori Kraljevine Jugoslavije: Biografski leksikon. Urednici Momčilo Pavlović, Nebojša Stambolija, Milan Gulić, 253. Beograd: Institut za savremenu istoriju, 2016.

- Dobaja, Dunja. „Socialna in zdravstvena problematika v obdobju Ljubljanske oblasti in Dravske banovine“. U: Marko Natlačen (1886-1942) v zgodovinskem dogajanju. Urednik Zdenko Čepič, 139-155. Ljubljana: Inštitut za novejšo zgodovino, 2012.

- „Ekspoze Ministra socijalne politike i narodnog zdravlja u narodnoj skupštini o budžetu Ministarstva za 1939-1940 godinu“. Socijalni arhiv, god. 5, br. 1-2, (1939), $1-5$.

- Lazarević, Žarko. Plasti prostora in časa: Iz gospodarske zgodovine Slovenije prve polovice 20. stoletja. Ljubljana: Inštitut za novejšo zgodovino, 2009.

- Gulić, Milan. „Cvetković Dragiša“. U: Senatori Kraljevine Jugoslavije: Biografski leksikon. Urednici Momčilo Pavlović, Nebojša Stambolija, Milan Gulić, 71-73. Beograd: Institut za savremenu istoriju, 2016.

- Meršol, Valentin. „O ljubljanski bolnici“. Zdravniški vestnik: strokovno glasilo zdravništva v dravski banovini, 1. 2, št. 8, (1936), 72-78.

- Meršol, Valentin. „Bolnišnice v Sloveniji“. U: Spominski zbornik Slovenije. Urednici Jože Lavrič, Josip Mal, France Stele, 490-506. Ljubljana: Jubilej, 1939.

- „Trpljenje v številkah“. Slovenec: političen list za slovenski narod, 16. 1. 1931, 8.

- „Zakon o bolnicah“. Uradni list kraljevske banske uprave dravske banovine, 1. 41, št. 1, (1930), 523-528.

- Zalokar, Alojz. „Pomanjkanje postelj in socialna služba v naših bolnicah“. Zdravniški vestnik: strokovno glasilo zdravništva v dravski banovini, 1. 8, št. 5, (1936), 211-216.

- Zupanič Slavec, Zvonka. Razvoj javnega zdravstva na Slovenskem med prvo in drugo svetovno vojno in njegov utemeljitelj dr. Ivo Pirc. Ljubljana: Inštitut za varovanje zdravja RS, 2005. 
DUNJA DOBAJA, PhD, assistant

Institute of Contemporary History

Ljubljana, Republic of Slovenia

dunja.dobaja@inz.si

\author{
HOSPITALS IN THE KINGDOM OF YUGOSLAVIA - \\ „DISADVANTAGED“ INSTITUTIONS OF THE CURATIVE BRANCH. \\ THE EXAMPLE OF THE GENERAL STATE HOSPITAL IN LJUBLJANA
}

\title{
Summary
}

The article focuses on the overcrowding of the General State Hospital in Ljubljana during the period between the wars, although this hospital also faced other personnel and staffing problems. The spatial problem exceeded the limits of the bearable and was not only a Slovenian, but to a large extent an allYugoslav problem. Criticisms regarding the poor financial, spatial, and staffing situation of hospitals were coming in from the banovinas (subdivisions of the state). The pressures on the central government to solve the problems were increasing. The state operated within its financial capabilities; especially during the period of the economic crisis, the Ministry of Social Policy and National Health could solve and regulate only the basic issues. The problem of hospitals was addressed more thoroughly by the Minister Dragiša Cvetković, who made concrete proposals for the drafting of a new act on hospitals. It seemed that things could slowly be put right, but the positive development was interrupted by the war. The spatial problem of the central Ljubljana hospital was not solved.

KEYWORDS: hospitals, Kingdom of Yugoslavia, Dravska Banovina, General State Hospital in Ljubljana, curative medicine 